\title{
Aldur og kjör sjálfstætt starfandi sérfræðilækna
}

\section{Kristján \\ Guð̋mundsson}

háls-, nef- og eyrnalæknir, formaður samninganefndar LR

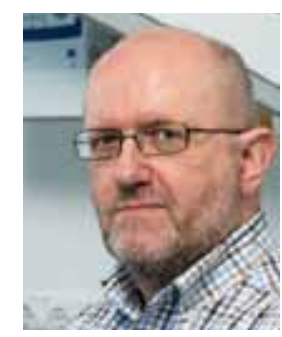

kristjang@centrum.is

Gera má ráð fyrir að hver Íslendingur hitti lækni 5 sinnum á ári. Petta eru svonefndar klínískar heimsóknir (myndgreininga- og rannsóknapjónusta undanskilin) í heilsugæslu, sérfræðipjónustu og á göngudeildum sjúkrahúsa, par með talið læknavaktir og bráđamóttökur. Um 30\% pessara heimsókna er sinnt af svokölluðum sjálfstætt starfandi sérfræðilæknum. Sú starfsemi hefur líka verið kölluð „opinn krani“. Frá apríl 2011 hafa engir samningar verið í gildi milli Læknafélags Reykjavíkur og Sjúkratrygginga Íslands og á peim tíma hafa engar „bremsur" verið á starfseminni, engir kvótar, afslættir eða takmarkanir á gjaldliðanotkun. Fjöldi heimsókna og heildarvelta hefur pó verið nánast óbreytt árin 2010, 2011 og 2012, pó hefur tiltölulega dýrum verkum fjölgað undanfarið, meðal annars með lokun St. Jósefsspítala í Hafnarfirði.

Sá hópur sem sinnir sérfræðilækningum á stofu telur um 340 lækna og hefur staðið nánast óbreyttur árum saman. Af pessum hópi er áætlað að um 140 læknar starfi eingöngu utan sjúkrahúsa en um 200 læknar séu líka í hlutastarfi á sjúkrahúsi.
Undirritaður skoðaði nýlega aldurssamsetningu sjálfstætt starfandi sérfræðilækna árin 2007 og 2012. Meðalaldur pessa hóps hefur hækkað um 5 ár á pessum tíma, sem pýðir á mannamáli að par hefur engin endurnýjun átt sér stað. Ef litið er til svokallaðra verkeininga og skoðað hvernig pær skiptast eftir aldri sérfræðinga, kemur í ljós að árið 2012 var 33\% starfseminnar sinnt af læknum 60 ára og eldri en 2007 var petta hlutfall aðeins 19\%. Sama er að gerast á hinum endanum. Árið 2007 voru $42 \%$ starfseminnar á hendi lækna 49 ára og yngri en petta hlutfall er dottið niður í 25\% árið 2012. Í töflu I má sjá skiptingu verkeininga eftir aldursflokkum árin 2007 og 2012. Samkvæmt upplýsingum frá Læknafélagi Íslands hafa mál próast á svipaðan veg annars staðar. Pannig hefur meðalaldur heilsugæslulækna farið úr 50 árum í 54 og sjúkrahúslækna úr 49 í 52 ár, reyndar frá 2007 til 2013. Pessi próun er afleit, hvernig sem á hana er litið. Ekki skal gert lítið úr starfi reyndra lækna, en pegar nýliðunin er svona léleg verður að bregðast við. Við vitum að sérfræðipjónustan hérlendis er mun ódýrari en sama pjónusta í nágrannalöndunum, löndunum par sem ungir læknar stunda sitt sérnám. Par bjóðast peim miklu betri kjör, ekki bara á sjúkrastofnunum heldur einnig í einkarekstri.

Svo lengi sem elstu menn muna hefur aðgengi ungra sérfræðilækna að samningi við Sjúkratryggingar, áđur Tryggingastofnun, verið opið eða pví sem næst. Læknasamtökin hafa reynt að standa vörð um petta ákvæði gegnum tíðina enda talið skipta miklu fyrir heimkomu lækna erlend- is frá. Peir hafa pá getað starfað á stofu og jafnframt verið í hlutastarfi á stofnun. Pessi hópur sem nú telur um 200 lækna á nokkuð undir högg að sækja. Kjarasamningar eru með peim hætti að læknar í hlutastarfi á sjúkrahúsi eru á lægra tímakaupi en læknar í fullu starfi vegna svokallaðs helgunarálags og munar pá oft tugum prósenta. Svona hefur petta verið í á annan áratug og er farið að torvelda mönnun á hlutastöðum. Svipuðu máli gegnir um laun yngstu læknanna, pau eru nú satt best að segja býsna lág miðað við námslengd og gera pað meðal annars að verkum að ungir læknar koma sér nú sem fyrst úr landi. Pegar vandi steðjar að heilbrigðiskerfinu er erfiðara að leysa hann með vitlaust gefið frá byrjun.

Tafla I.

\begin{tabular}{ccc}
\hline & \multicolumn{2}{c}{$\%$ af heildareiningum } \\
\hline Aldur & 2007 & 2012 \\
\hline$<40$ & 5,21 & 0,91 \\
\hline $40-44$ & 9,93 & 11,80 \\
\hline $45-49$ & 27,07 & 11,91 \\
\hline $50-54$ & 17,33 & 26,34 \\
\hline $55-59$ & 21,77 & 15,83 \\
\hline $60-64$ & 10,31 & 19,15 \\
\hline $65-69$ & 5,71 & 9,09 \\
\hline $70+$ & 2,68 & 4,79 \\
\hline
\end{tabular}

and earnings of specialists Kristjan Gudmundsson ENT-specialist, Medical Clinic, Álfheimum 74, Reykjavík

Chairman, ambulatory services reimbursement committee 